\title{
Konflikt chińsko-tajwański w ujęciu paradygmatu realistycznego - trzy poziomy analizy Kennetha Waltza
}

\section{Uwagi wstępne}

7 łożoność współczesnych stosunków międzynarodowych implikuje konieczność wykorzystania możliwie jak najbardziej holistycznego, kompleksowego podejścia w analizie przyczyn i dalszych konsekwencji trwających konfliktów. Listę możliwych wyjaśnień konfliktu między Chinami a Tajwanem można uporządkować według trzech poziomów analizy, które po raz pierwszy zostały przedstawione przez Kennetha Waltza w Man, the State and War z 1959 r., a rozszerzone przez J. Davida Singera. Zgodnie z założeniami Waltza przyczyn wojen należy upatrywać na trzech poziomach analizy: jednostki - skupiając się na jej egoistycznej naturze i osobowości, państwa - maksymalizującego za wszelką cenę swoją potęgę, systemu międzynarodowego - czyli funkcjonowania państw w warunkach anarchii, która nie przeciwdziała wojnom, a wręcz przeciwnie - brak władzy nadrzędnej nie stanowi przeszkód do ich wybuchu i dalszej eskalacji ${ }^{1}$.

W celu dokonania dogłębnych i szczegółowych wyjaśnień konfliktu chińsko-tajwańskiego niniejsze rozważania będą skoncentrowane na wszystkich trzech poziomach przedstawionych przez Kennetha Waltza. Kiedy przedstawiciele tradycyjnej perspektywy realistycznej skupiają uwagę na specyfice państw jako aktorach funkcjonujących w anarchicznym systemie międzynarodowym, Kenneth Waltz idzie o krok dalej i zauważa, że to zmienne na poziomie systemu międzynarodowego, będące siłą napędową kształtujących się stosunków międzynarodowych, odgrywają niebagatelną rolę w zapewnieniu odpowiedniego poziomu bezpieczeństwa. Zatem celem neorealistów (realistów strukturalnych) pozostaje próba odpowiedzi na

1 K.N. Waltz, Man, the State, and War: A Theoretical Analysis, New York 2001. 
pytanie, w jaki sposób na politykę prowadzoną przez poszczególne państwa wpływają zarówno czynniki wewnętrzne, chociażby rodzaj rządów, systemu gospodarczego czy działania grup interesów, jak i czynniki zewnętrzne - charakter międzynarodowego, anarchicznego systemu, który skutkuje słabością organizacji międzynarodowych, niebędących w stanie przeciwdziałać zaistniałym konfliktom. W rozumieniu Kennetha Waltza szczególnym wyznacznikiem polityki zagranicznej pozostaje system międzynarodowy. Brak nadrzędnej władzy intensyfikuje możliwości państw i warunkuje stopień międzypaństwowej interakcji, jednak należy pamiętać, że bez realnej wiedzy o jednostce i innych czynnikach wewnętrznych występujących w danym państwie niemożliwa pozostaje odpowiedź na pytanie, co tak naprawdę determinuje współczesne konflikty².

Autorka ma na uwadze fakt, iż analizę można również oprzeć na założeniach przedstawionych przez liberalistów czy konstruktywistów, którzy nawiązywaliby do idei i norm oraz tożsamości jednostek wpływających na istnienie konfliktu chińsko-tajwańskiego. Paradygmat realistyczny, a szczególnie założenia teorii realizmu strukturalnego, wydały się autorce najbardziej adekwatne, gdyż stanowią najszersze wyjaśnienie przyczyn występowania wojen pomimo doczekanej krytyki, jak również wyraźnych ograniczeń. Należy również pamiętać, że nie ma jednolitego realizmu, a raczej, że jest kilka „realizmów”, które w różnorodny sposób pojmują główne twierdzenia, takich jak: realizm klasyczny, strukturalny czy neoklasyczny. Zatem w tym kontekście autorka zawęży niniejszą analizę, koncentrując uwagę na ogólnych założeniach realizmu neoklasycznego.

\section{Czynnik ludzki w konflikcie chińsko-tajwańskim}

Od 1683 r. Tajwan należał do Chin, jednak sytuację zmieniła wojna chińsko-japońska, w wyniku której obszar wyspy usytuowanej na południowym wybrzeżu Chin na mocy traktatu z Shimonoseki stał się częścią Japonii w 1895 r. Ponadto w 1928 r. pod przywództwem Chiang Kai-sheka ${ }^{3}$

2 T. Tamaki, Levels of analysis of the international system, [w:] Encounters with World Affairs: An Introduction to International Relations, ed. E. Kavalski, Farnham 2015, s. 86-87; A.A. Omar, Is there anything 'new' in neoclassical realism?, 13.02.2013, http://www.e-ir. info/2013/02/13/is-there-anything-new-in-neoclassical-realism/ [dostęp: 16.08 2017].

3 W języku mandaryńskim Jiang Zhongzheng [czyt. Czang Kaj-szek]. 
reprezentującego Kuomintang ${ }^{4}$ Republika Chińska objęła kontrolą większą część kontynentalnych Chin. W lipcu 1937 r. w obliczu japońskiej okupacji Komunistyczna Partia Chin oraz Chińska Partia Narodowa zdecydowały się podjąć współpracę w celu eliminacji przeciwnika. Przez kilka lat obie partie tworzyły antyjapoński blok, a w chwili, gdy zwycięstwo było już przesądzone, lider nacjonalistycznej partii Guomingangu Chiang Kai-shek i Komunistycznej Partii Chin Mao Tse-tung spotykali się w Chongqingu, aby ogłosić wspólny sukces. Niewątpliwie było to ostatnie spotkanie, w którym deklarowali współpracę, bo w 1946 r. wybucha kolejna wojna domowa zapoczątkowana atakiem Chiang Kai-sheka na terytorium kontrolowane przez komunistów ${ }^{5}$. Jednak pozycji Chińskiej Partii Narodowej nie sprzyjał kryzys gospodarczy oraz widoczne przejawy dyskryminacji stosowane przez autorytarny, skorumpowany rząd. Represje wobec japońskiej ludności odcisnęły swoje piętno również na pozostałych mieszkańcach Tajwanu, podejrzewanych o kolaborację z byłymi władzami okupacyjnymi, co doprowadzało w 1947 r. do krwawych demonstracji tajwańskiej ludności przeciwko Guomingangowi, a w dalszej perspektywie do całkowitego podporządkowania Tajwanu partii nacjonalistycznej ${ }^{6}$. Nic więc dziwnego, że Tajwan, kontrolowany od wydarzeń z 28 lutego przez Chińską Partię Narodową, został uznany w 1949 r. za naturalne schronienie Chiang Kai-sheka po przegranej wojnie domowej z komunistami. Kiedy 1 października 1949 r. Mao Tse-tung ogłosił powstanie Chińskiej Republiki Ludowej (ChRL), przez lata część zwolenników Chiang Kai-sheka uznawała jego rządy za jedyne legalne i reprezentujące całe Chiny ${ }^{7}$. Do końca lat 70. Republika Chińska z Tajwanu występowała w imieniu Chin w ONZ,

\footnotetext{
4 Partia nazywana jest zamiennie Kuomintangiem bądź Chińską Partią Narodową.

5 S. Ya-Chen, Political Ideology and Taiwanese School Curricula, „Asia Pacific Education Review" 2006, Vol. 7, No. 1, s. 42; E. Albert, China-Taiwan Relations, 7.12.2016, https://www. cfr.org/backgrounder/china-taiwan-relations; P. Zieliński, Kryzys tajwański 1958 roku, http:// www.konflikty.pl/historia/czasy-najnowsze/kryzys-tajwanski-1958-roku/ [dostęp: 16.08 2017].

6 Bezpośrednią przyczyną wybuchu zamieszek było zabójstwo 40-letniej kobiety oskarżonej o nielegalny handel wyrobami tytoniowymi, w wyniku czego mieszkańcy Tajwanu wszczęli zamieszki. Według danych szacunkowych zginęło wówczas 10 tys. Tajwańczyków, a wśród nich członkowie miejscowej elity. S. Ya-Chen, Ideological Representations of Taiwan's History: An Analysis of Elementary Social Studies Textbooks, 1978-1995, „Curriculum Inquiry” 2007, Vol. 37, No. 3, s. 206-208; P.C. Cheng, Taiwan under Chiang Kai-shek's era: 1945-1976, „Asian Profile" 1988, Vol. 16, No. 4, s. 300-301.
}

7 M. Dillon, Chiny. Historia współczesna, Warszawa 2012, s. 465-466. 
jak i innych organizacjach międzynarodowych, a zwolennicy Chiang Kai-sheka w dalszym ciągu wierzyli, że uda mu się odzyskać władzę w Nankinie. Jednakże dla Chińskiej Republiki Ludowej pod rządami Mao Tse-tunga Tajwan był schronieniem pokonanej już partii Guomindangu, jak również prowincją, która miała być ostatecznie kontrolowana przez Chiny i pozostać pod zwierzchnią władzą partii komunistycznej ${ }^{8}$.

Z punktu widzenia klasycznych realistów przyczyn konfliktu chińsko-tajwańskiego można upatrywać na poziomie jednostki i jej chęci dążenia do władzy. Realiści uważają, że jednostka kieruje się egoizmem, jest zepsuta i samolubna i tym samym troszczy się tylko i wyłącznie o własne interesy. Dodatkowo konflikt leży w naturze ludzkiej, a stan braku bezpieczeństwa jest cechą ludzkiego życia. Zgodnie z założeniami realizmu strukturalnego oczywisty pozostaje zatem wpływ przywództwa politycznego na zmianę polityki zagranicznej państw. Ponadto zgodnie z twierdzeniami Reinholda Niebuhra, aby w obrębie polityki osiągnąć swoje cele, często można dopuszczać się czynów, które w sferze prywatnej uchodzą za niemoralne, co wyjaśnia bezwzględną strategię prowadzoną zarówno przez Chiang Kai-sheka, jak i Mao Tse-tunga - okrutnego dyktatora Chińskiej Republiki Ludowej ${ }^{9}$.

W myśl założeń paradygmatu realistycznego jedną z przyczyn konfliktu chińsko-tajwańskiego mogła być obsesyjna chęć powrotu na kontynent generalissimusa Chiang Kai-sheka ${ }^{10}$. Cechowała go zaskakująca siła charakteru i wiara w to, że bez wsparcia Stanów Zjednoczonych jest w stanie objąć silne przywództwo odznaczające się „tradycyjnymi wartościami”. Jego nadzieje mogło również podsycić spotkanie z McArthurem. Samo uznanie rządu w Tajpej przez Amerykanów oraz ONZ jako reprezentującego całe Chiny przybliżało możliwość ponownego objęcia władzy. Chiang Kai-shek marzył o stworzeniu wielkiego imperium. W tym celu usilnie eliminował opozycję oraz wprowadził na Tajwanie 38-letni stan wojenny. We wrześniu 1947 r. generalissimus stwierdził:

Choć (komuniści, organizacja, szkolenie, techniki propagandowe itd.) są lepsze od naszych, nasza ideologia, myśl i (polityczna) linia są jed-

8 Ibidem, s. 466; K. Dumbaugh, Taiwan's political status: historical background and its implications for U.S. policy, 3.11.2009, https://fas.org/sgp/crs/row/RS22388.pdf [dostęp: 17.08.2017].

9 J. Donnelly, Realism and international relations, Cambridge 2000, s. 48.

10 W języku mandaryńskim Jiang Zhongzheng [czyt. Czang Kaj-szek]. 
nak zdecydowanie bardziej poprawne niż ich i są ponadto bardziej dostosowane do potrzeb narodu. Dlatego też, jeśli tylko będziemy mogli przestudiować wszystko i zrozumieć wszystko, wtedy możemy mieć pewność ich unicestwienia ${ }^{11}$.

Z drugiej strony, analizując poczynania Mao Tse-tunga, można dojść do wniosku, że podobnie jak w przypadku Chiang Kai-sheka motorem jego działań była niekończąca się walka o potęgę, której realiści przypisują istotne znaczenie. Hans Morgenthau definiuje potęgę jako psychologiczną relację występującą między władzą a jednostkami jej poddanymi, czyli:

zdolność do kontroli, którą można sprawować za pośrednictwem rozkazów, gróźb, autorytetu lub charyzmy człowieka lub urzędników, bądź kombinacji tych czynników ${ }^{12}$.

Mao, aby zaspokoić swoje ego, chętnie uciekał się do bestialskich egzekucji, a w wyniku jego postępowania śmierć poniosły miliony ofiar. Przewodniczący Komitetu Politycznego Komunistycznej Partii Chin okazał się jednak dysponować skuteczniejszymi siłami. Jednak podobnie jak Chiang Kai-shekowi, będącemu przywódcą partii Guomindangu i uważającego siebie za prezydenta kraju oraz dowódcę sił zbrojnych, Mao nie brakowało charyzmy ani zdolności konsolidacyjnych wśród komunistycznych zwolenników. Ideologia komunistyczna miała zjednoczyć wszystkie klasy rewolucyjne, począwszy od chłopstwa, a skończywszy na narodowej burżuazji. Propaganda oraz szerzony kult wodza okazały się skutecznie wpływać na mieszkańców Chin, oczekujących szybkiej poprawy jakości życia, czego nie gwarantowały rządy Chiang Kai-sheka. Dodatkowo z punktu widzenia realizmu konflikt między Chiang Kai-shekiem a Mao Tse-tungiem można rozpatrywać również z uwzględnieniem personalnych przesłanek - chęć rywalizacji między sobą dwóch przywódców była widoczna praktycznie od początku ich politycznych rozgrywek ${ }^{13}$.

11 L.E. Eastman, Who lost China? Chiang Kai-shek testifies, „The China Quarterly” 1981, No. 88, s. 661-662.

12 R. Kwieciński, Między „republika” a „imperium”? Chiny w stosunkach międzynarodowych $w$ ujęciu paradygmatu realistycznego, [w:] Teoria realizmu w nauce o stosunkach międzynarodowych: założenia i zastosowania badawcze, red. E. Haliżak, J. Czaputowicz, Warszawa 2014, s. 373.

13 P.C. Cheng, op.cit., s. 301-302; H.M. Tanner, Where Chiang Kai-shek lost China: The Liao-Shen campaign, 1948, Bloomington 2015, s. 20-24; J. Fenby, Czang Kaj-Shek i jego Chiny. Jeden z najbardziej kontrowersyjnych przywódców XX wieku, Wrocław 2003, s. 200-202. 
Kolejni przywódcy również nie rozwiązali istniejącego konfliktu. Po śmierci Chiang Kai-sheka prezydentem Tajwanu został dotychczasowy wiceprezydent Yen Chia-kang, jednak w praktyce władzę sprawował syn Chiang Kai-sheka Chiang Ching-kuo. W marcu 1986 r. Chiang Ching-kuo znacznie zmienił tor polityki prowadzonej przez ojca. Zniósł zakaz tworzenia partii politycznych oraz stworzył system parlamentarny. Polityka prowadzona przez Chianga Ching-kuo również może być kojarzona z realistycznym punktem widzenia. Chiang Ching-kuo doskonale gospodarował zasobami wyspy, aby stopniowo doprowadzić do rozwoju potencjału gospodarczego i tym samym tworzył podwaliny silnego państwa. Do organów ustawodawczych weszli politycy, którzy dążyli do prawdziwej niepodległości Tajwanu i nie rościli sobie prawa do rządów na kontynencie. Kiedy w 1988 r. władzę objął Lee Teng-hui, zarówno strona tajwańska, jak i chińska wierzyły w zjednoczenie, ale w dalszym ciągu nie były gotowe do kompromisu. Lee Teng-hui odważył się wydać oświadczenie, które uznano za krok ku niepodległości Tajwanu, ale ponieważ bał się negatywnej reakcji ze strony Chin, został wykluczony z Guomindangu. Jego następca Chen Shui-bian (Demokratyczna Partia Postępowa), wybrany na prezydenta po pięćdziesięcioletnim panowaniu Guomindangu, nigdy nie odważył się poruszać sprawy Tajwanu w kontaktach z Pekinem. W 2008 r. nastąpił powrót do władzy Guomindangu, za którego kadencji porozumienie w dalszym ciągu nie zostało wypracowane ${ }^{14}$. W wyborach w 2016 r. zwyciężyła Demokratyczna Partia Postępowa (DPP), a stanowisko prezydenta objęła Tsai Ing-wen - pierwsza w historii kobieta piastująca najwyższy urząd. Od początku kadencji Tsai Ing-wen zaostrza retorykę wobec Pekinu, żądając aresztowania winnych masakry z 28 lutego 1947 r., jak również oficjalnie przyznając, że chińska polityka coraz silniej uderza w położenie Tajwanu. Jednak niezależnie od stanowiska Tsai Ing-wen i uznania wyspy za niezależny obszar na chwilę obecną nie można zaobserwować tendencji, które miałyby zmienić status quo Tajwanu, ekonomicznie uzależnionego od Państwa Środka ${ }^{15}$.

14 M. Dillon, op.cit., s. 468-474.

15 http://www.straitstimes.com/asia/east-asia/taiwan-president-vows-thorough-probe-into-1947-massacre. http://www.latimes.com/world/asia/la-fg-taiwan-tsai-approval2017-story.html [dostęp: 19.08.2017]. 


\section{Znaczenie czynników państwowych w casusie chińsko-tajwańskim}

Zdaniem realistów podstawowym celem państwa jest zapewnienie narodowego bezpieczeństwa i dobrobytu narodu ${ }^{16}$. Państwa za wszelką cenę starają się z jednej strony utrzymać, a z drugiej zwiększyć własną potęgę, gdyż wzmacnia ona ich bezpieczeństwo i warunkuje realizację strategicznych celów. We współczesnych stosunkach międzynarodowych, aby mówić o roli państwa, należy wziąć pod uwagę nie tylko zdolności militarne, ale również potencjał gospodarczy i polityczny ${ }^{17}$. Zatem zdaniem Kennetha Waltza potęga nie jest dziś „hegemoniczna”, ponieważ siła militarna nie w każdym przypadku będzie prowadzić do zwiększenia wpływów politycznych. Aby mówić o tym, że dane państwo może uzyskać status supermocarstwa, można wziąć pod uwagę tylko jeden z czynników uznanych za potęgotwórczy, m.in.: położenie geograficzne, potencjał ludnościowy i surowcowy, poziom gospodarczy, zasobów finansowych, możliwości wojskowo-technologiczne. Istotną rolę odgrywają również kwestie niematerialne, takie jak: narodowe morale, przywództwo (jego etos i autorytet), prestiż, historia oraz ideologia ${ }^{18}$. Dla Kennetha Waltza potęga Chin koncentruje się na obszernych zasobach ludnościowych, co nie oznacza, że Chiny nie mogą rozwijać innych płaszczyzn skłaniających do uznania państwa za mocarstwo ${ }^{19}$. Zgodnie z realizmem strukturalnym, a dokładniej realizmem ofensywnym, państwa dążą do maksymalizacji potęgi. W oczach realistów działanie Chin jest skoncentrowane na wykluczaniu. Hans Morgenthau stwierdził, że nie każdą politykę, która podejmuje wysiłki w celu zwiększenia potęgi państwa, można nazwać imperialistyczną. Jednakże każda polityka zagraniczna dążąca do zachowania obecnego imperium może być za taką uznana. Do takich państw można zaliczyć m.in. Chiny, które mając

16 T. Łoś-Nowak, Państwowy poziom analizy w stosunkach międzynarodowych, [w:] Poziomy analizy stosunków międzynarodowych, red. E. Haliżak, M. Pietraś, t. 1, Warszawa 2013, s. 27.

17 D. Singer, The level-of-analysis problem in international relations, „World Politics” 1961, Vol. 14, No. 1, s. 82-85.

18 A. Bógdał-Brzezińska, Mocarstwowość w teorii stosunków międzynarodowych, [w:] Państwo $w$ teorii i praktyce stosunków międzynarodowych, red. M. Sułek, J. Simonides, Warszawa 2009, s. 98-99.

19 Waltz K., Struktura teorii stosunków międzynarodowych, Warszawa 2010, s. 135. 
mocarstwowe aspiracje, realizują strategię opartą na imperialnych metodach. Praktykowanie imperialnej polityki pozostaje szczególnie widoczne w kształtowaniu stosunków z innymi aktorami, m.in. z Tajwanem. Zatem celem działań realizowanych przez Państwo Środka jest zabezpieczenie dotychczasowych zdobyczy oraz stabilizacja związana z powstaniem tego imperium $^{20}$. Realiści mogliby zatem uznać, że przyczyną, dla której Chinom zależy na tym, aby Tajwan był uznany za integralną część Chin, jest właśnie kontekst polityki imperialistycznej. Wyspa od stuleci należała do Chin, zaś w XIX w. została zawłaszczona przez kolonializm japoński ${ }^{21}$. Chińczycy starają się więc odzyskać potęgę, którą przez lata budowali.

Najważniejszymi kwestiami, wokół których koncentruje się Państwo Środka w sprawie Tajwanu, są punkty przedstawione przez Hu Jintao w 2008 r. Jednym z nich jest zasada ,jednych Chin” interpretowana dwojako przez strony konfliktu. Według Chińskiej Republiki Ludowej to ona jest reprezentantem „jednych Chin”. Problem polega jednak na tym, że za narodowego przedstawiciela uważa się również Republika Chińska ${ }^{22}$. Ponadto Chiny myślą w kategoriach własnego interesu narodowego. Działania przez nie podejmowane są z punktu widzenia realizmu całkowicie racjonalne. Korzyści, jakie osiągnęłoby Państwo Środka, doprowadzając do uznania władz pekińskich za jedynego reprezentanta, można podzielić na kwestie militarne, polityczne i ekonomiczne. W wymiarze militarnym Cieśnina Tajwańska należy do najbardziej uczęszczanych szlaków morskich. Gdyby więc Chiny zapa-

20 W 1902 r. John Atkinson Hobson doszedł do wniosku, że mocarstwa powstały dzięki wyzyskowi i niewłaściwej dystrybucji bogactwa, do czego doprowadziły przez rozszerzenie rodzimych rynków na rynki zagraniczne, co wiązało się z chęcią zwiększenia zysków. W XX w. na myśli Hobsona oparł się Włodzimierz Lenin, który uznał, że imperializm to najwyższe stadium kapitalizmu. Zachodnie kraje znajdujące się w fazie imperializmu nazwał ograbiającymi resztę świata „pasożytami”, dzielącymi między sobą światowe wpływy. Z terminem mocarstwowości niekiedy błędnie utożsamia się imperializm. Kiedy to pierwsze odnosi się do pewnych cech, które przejawia mocarstwo, drugie dotyczy polityki państwa będącego czy aspirującego do statusu mocarstwa. Ekspansjonistyczne imperium w wyniku podbojów kontroluje tereny wykraczające poza jego granice. H. Morgenthau, Polityka między narodami. Walka o potęge i pokój, red. K.W. Thompson, tłum. R. Włoch, wydanie skrócone, Warszawa 2010, s. 74-75; J.A. Hobson, Imperialism: a Study, London 1988; W.I. Lenin, Imperializm jako najwyższe stadium kapitalizmu: szkic popularny, Warszawa 1949.

21 G. Valentini, China and Japan's Responses to the West in the $19^{\text {th }}$ Century, 4.11.2013, http://www.e-ir.info/2013/11/04/chinese-and-japanese-responses-to-the-west-during-the19th-century/ [dostęp: 20.08 2017].

22 R.C. Bush, A One-China policy primer, „East Asia Policy Paper” 2017, No. 10, s. 5. 
nowały nad tym regionem, byłyby zdolne do wywierania wpływu na Koreę czy Japonię, które zaopatrywane są tą drogą chociażby w paliwa. Dodatkowo Pekin mógłby zabezpieczyć ekonomiczne interesy nadbrzeżnych prowincji oraz poszerzyć strefę chińskiej kontroli. Dopiero gdyby doszło do faktycznego zagrożenia ze strony USA, musiałby wykorzystać znacznie oddalone bazy. Do politycznych przesłanek działań Chińskiej Republiki Ludowej można zaliczyć fakt, że gdyby Tajwan powrócił do terytorium Chin, nierównoprawne traktaty ciążące Pekinowi od XIX w. odeszłyby w zapomnienie. Odpuszczenie sprawy Republiki Chińskiej doprowadziłoby również do ożywienia nadziei wśród innych prowincji, które mają już sporą autonomię. Ponadto Chiny pragną odgrywać wspomnianą już rolę mocarstwa w regionie. Brak zjednoczenia Tajwanu z Chinami skutkowałby utratą prestiżu i pozycji Chin, które potraktowano by jako niezdolne do zachowania spójności terytorium. W kwestii ekonomicznej konsekwencją przejęcia Tajwanu byłaby możliwość wykorzystania potencjału rezerw finansowych oraz jej zaawansowanego przemysłu ${ }^{23}$.

Oprócz procesów decyzyjnych oraz innych wewnętrznych mechanizmów wpływ na politykę zagraniczną ma również dla realistów charakter państwa - demokratyczny lub niedemokratyczny. Fakt, że ustrój w Chinach jest zdominowany przez Komunistyczną Partię Chin, odgrywa ogromne znaczenie w podejmowanych przez nie działaniach. Z drugiej strony Tajwan jest postrzegany jako demokratyczny, wolny, pokojowy i stanowi przeciwwagę dla agresywnego, ograniczającego swobody Państwa Środka ${ }^{24}$. W Republice Chińskiej tylko dwie partie cieszą się większym poparciem społecznym - Guomindang oraz Demokratyczna Partia Postępowa. Obie inaczej postrzegają możliwość zakończenia konfliktu. Pierwsza z nich skupia się bardziej na zjednoczeniu dwóch terytoriów, zaś druga opowiada się za niepodległością. Tajwan oraz Chiny różnią się również systemem gospodarczym, który w tym pierwszym traktowany jest jako kapitalistyczny, zaś gospodarka chińska łączy w sobie cechy kapitalizmu oraz socjalizmu, silnie podporządkowując kwestie gospodarcze polityce państwa ${ }^{25}$.

23 B.S. Zemanek, Tajwańska tożsamość narodowa w publicystyce politycznej, Kraków 2008, s. 84-85.

24 Ibidem, s. 126.

25 Rozwój gospodarczy zapoczątkował Deng Xiaoping, wprowadzając reformy zgodne z zasadą „budowy socjalizmu o chińskiej specyfice”. L. Xing, T.M. Shaw, The political economy of 
Gdyby wziąć pod uwagę działania podejmowane przez Tajwan, również z punktu widzenia paradygmatu realistycznego będą one racjonalne, nakierowane na własne bezpieczeństwo i ochronę interesów. Przyczyną dynamicznego rozwoju gospodarczego wyspy od 1945 r. była m.in. chęć przetrwania Guomindangu. Niewątpliwie udział w błyskawicznym rozwoju miały również Stany Zjednoczone, które przekazywały Tajwanowi pakiety pomocowe, a od 1965 r. pozyskiwały od Tajwanu broń wykorzystywaną w wojnie wietnamskiej. Jednocześnie rząd w Tajpej zaczął wprowadzać w życie program Sun Yat-sena nazwany „ziemią dla oracza”. Po redukcji renty gruntowej dla dzierżawców ziem zaczęto wysprzedawać grunty stanowiące własność publiczną, należące uprzednio do japońskiej administracji, która traktowała ziemie na Tajwanie jako zachętę do przyjazdu z Japonii i osiedlenia się na wyspie. Po udanej transformacji w rolnictwie wprowadzono czteroletni plan gospodarczy, dzięki któremu zwiększyła się liczba małych i średnich przedsiębiorstw odnotowujących coraz większe zyski z eksportu towarów. Stopniowo modernizowano infrastrukturę, rozwijano przemysł, wspierano oświatę. Zmiany wymusiły przede wszystkim polityka prowadzona przez Chiny oraz świadomość, że pomoc amerykańska nie będzie trwała nieprzerwanie ${ }^{26}$. Dzięki rozwojowi gospodarczemu Tajwan zabezpieczył swoje fundamentalne interesy, choć w tym kontekście warto zaznaczyć, że założenia paradygmatu liberalnego, przekonanego o nieopłacalności toczenia wojen w przypadku handlowej współzależności, w casusie chińsko-tajwańskim nie odpowiadają obecnym relacjom. Sprzyjająca koniunktura stanowiła dla Tajwanu okazję do ustanowienia przeciwwagi dla Chińskiej Republiki Ludowej, co nie zaowocowało współpracą, która mogłaby zagwarantować w przyszłości pokój. Pomimo znacznej poprawy w relacjach chińsko-tajwańskich w dalszym ciągu obecne pozostają próby wzmacniania politycznej konfrontacji, widoczne chociażby w wynikach sondaży, które jednoznacznie wskazują, że systematycznie wzrasta liczba osób popierających starania o uzyska-

Chinese state capitalism, „The Journal of China and International Relations” 2013, Vol. 1, No. 1, s. 88-89; K. Karnia, China's capitalism, „Warsaw Forum of Economic Sociology” 2012, Vol. 3, No. 1 (5), s. 84.

26 M. Dillon, op.cit., s. 464-465. K.C. William, The Nationalist Regime and the Chinese Party-State, 1928-1958, [w:] Historical Perspectives on Contemporary East Asia, eds. M. Goldman, A. Gordon, Cambridge 2000, s. 219. 
nie przez Tajwan statusu niezależnego państwa. W 1998 r. tylko 10-15\% tajwańskiej społeczności było zgodnych co do konieczności separacji od Chińskiej Republiki Ludowej, ale już w 2015 r. pomimo 65,2\% deklaracji respondentów o chęci zachowania status quo przy wyborze pomiędzy „niezależnością” a „zjednoczeniem” 68,9\% ankietowanych opowiedziało się za tajwańską niezależnością ${ }^{27}$.

Z drugiej jednak strony od chwili, kiedy Republika Chińska przestała być pełnoprawnym członkiem ONZ, nastąpiła jej stopniowa izolacja, lecz dzięki rozwojowi gospodarczemu nie poszła w parze z izolacją ekonomiczną. Zgodnie z teorią liberalną można wysnuć jednak wniosek, że w chwili obecnej Tajwan jest za bardzo atrakcyjnym państwem, aby pozostałe gospodarki mogły pozwolić sobie na jego zignorowanie, lecz kontakty między Chinami a Tajwanem można przyrównać do gry o sumie zerowej, kiedy przegrana jednej strony prowadzi do wygranej drugiej, co niewątpliwie pozostaje bliższe przedstawicielom realizmu ${ }^{28}$.

\section{Rola systemu międzynarodowego}

Kiedy w latach 40. XX w. chińscy komuniści otrzymali wsparcie ze strony Stalina, od zwolenników Chiang Kai-sheka odsunęły się Stany Zjednoczone, początkowo wspomagające działania partii nacjonalistycznej. W styczniu 1950 r. prezydent Truman, wydając białą księgę, stwierdził, że jego administracja nie zaangażuje się w wojskową czy doradczą pomoc dla sił chińskich ${ }^{29}$. Jednak gdy Komunistyczna Partia Chin poparła wojnę w Korei, prezydent Truman zdecydował się wydać rozkaz podjęcia walk przez Siódmą Flotę USA w Cieśninie Tajwańskiej, aby osłonić wyspę przez chińskim wrogiem ${ }^{30}$.

27 Tse-Kang Leng, Dynamics of Taiwan-mainland China economic relations: the role of private firm, „Issues and Studies” 1998, s. 4-6, https://www.forbes.com/sites/jnylander/2015/02/14/ strong-support-for-independence-in-taiwan/\#79b46457281d [dostęp: 21.08.2017].

28 A. Ziętek, Aktualne problemy polityki zagranicznej Republiki Chińskiej na Tajwanie, [w:] Tajwan w stosunkach międzynarodowych, red. E. Haliżak, Warszawa 1997, s. 62-63.

29 J. Polit, Chiny, Warszawa 2004, s. 189.

30 Zaangażowanie USA w konflikt między Chinami a Tajwanem sprawiło, że dalszy jego przebieg został uzależniony od sytuacji na arenie międzynarodowej. Operacja USA na obszarze Cieśniny Tajwańskiej trwała aż do 1979 r., gdyż realia zimnej wojny sprawiły, iż obawiano się dalszego rozprzestrzenienia kryzysu tajwańskiego. Problem dotyczył również wysokiego 
8 września 1951 r. Japonia zrzekła się praw, tytułów i roszczeń do Tajwanu oraz Wysp Rybackich, ale w podpisanym traktacie nie uwzględniono adnotacji, na rzecz którego państwa podjęto takie działania. Dlatego znaczące pozostawało pytanie, czy Chiny odzyskają terytoria, które siłą zagarnęła Japonia. Sytuację problematyzowało niejednolite stanowisko pozostałych aktorów. Wielka Brytania nie uznała rządu utworzonego na Tajwanie, natomiast Stany Zjednoczone przed wybuchem wojny koreańskiej oficjalnie przyznały, że Tajwan jest częścią Chin i nawoływały do większej agresji wobec Komunistycznej Partii Chin, obiecując Chiang Kai-shekowi polityczne i militarne wsparcie. Szybko jednak zmieniły swoje stanowisko, podtrzymując postawę Wielkiej Brytanii ${ }^{31}$. Z kolei w ZSRR wyrażono pogląd, że problem Tajwanu został rozwiązany w aktach kończących wojnę na Dalekim Wschodzie, dlatego od 1949 r. powinien zostać uznany tylko Centralny Rząd Ludowy ${ }^{32}$.

Anarchiczny system międzynarodowy w przypadku Republiki Chińskiej na Tajwanie ma swoje odzwierciedlenie w braku możliwości określenia statusu prawnomiędzynarodowego. Obszar Tajwanu (dokładniej Tajwan, Wyspy Rybackie, grupa wysp Matsu i Quemoy) może być pojmowany jako państwo, część państwa lub zupełnie coś innego. Jednak pomimo tego Tajwan został określony przez niektóre państwa jako „państwo nieuznane” bądź „terytorium sui generis”, więc nie może być traktowany jako podmiot prawa międzynarodowego, chociaż wiele krajów pozostaje skłonnych utrzymywać z wyspą nieoficjalne stosunki. Z punktu widzenia realistów problem Tajwanu polega na tym, iż nie istnieje żadna władza międzynarodowa, która mogłaby uregulować pozycję Tajwanu. Dodatkowe trudności implikuje fakt wspomnianej już wieloletniej reprezentacji Chin przez Taj-

prawdopodobieństwa przejęcia Tajwanu przez Chiny, których działania mogły doprowadzić do wybuchu kolejnej wojny światowej. Należało zatem naturalnie oddzielić skonfliktowanych aktorów, tworząc swoisty bufor. Za kolejną przyczynę wykorzystania amerykańskich sił w $1950 \mathrm{r}$. uznaje się chęć nałożenia na Chińską Republikę Ludową embarga, którego wykonanie pozostawało pod kontrolą Siódmej Floty. B.A. Elleman, High seas buffer. The Taiwan patrol force, 1950-1979, Newport 2012, s. 3.

31 H. Matsumoto, The First Taiwan Strait Crisis and China's 'Border' Dispute around Taiwan, „Eurasia Border Review 3” 2012, s. 78.

32 L. Antonowicz, Status prawnomiędzynarodowy Republiki Chińskiej na Tajwanie, [w:] Tajwan w stosunkach..., op.cit., s. 33-35; S. Vradiy, Russia's unofficial relations with Taiwan, [w:] Eager Eyes Fixed on Eurasia, Vol. 2: Russia and Its Eastern Edge, ed. I. Akiriho, Hokkaido 2007, s. 221. 
wan w Organizacji Narodów Zjednoczonych. Wyżej wymieniona sytuacja trwała do 25 października 1971 r., gdy w drodze rezolucji postanowiono ponownie uznać reprezentację Chińskiej Republiki Ludowej, zachowując również dotychczasowe prawa Republiki Chińskiej ${ }^{33}$.

Z punktu widzenia realistów kwestią wartą szczególnej uwagi pozostaje niestabilność anarchicznego systemu, dlatego właśnie państwa muszą być gotowe, aby na siłę odpowiedzieć tylko i wyłącznie siłą. Przemoc i wojna są nieodłącznymi elementami systemu międzynarodowego ${ }^{34}$. Nie istnieje nadrzędna władza, która rozwiązałaby konflikt. Do powstania konfliktu przyczynia się również słabość organizacji międzynarodowych, w tym przypadku ONZ, która pomimo że stawia sobie za cel zapewnienie pokoju, w kwestii Chin i Tajwanu nie wypracowała skutecznych restrykcji, które mógłby ustabilizować sytuację. Warto też dodać, że Tajwan zajmował stałe miejsce w Międzynarodowym Funduszu Walutowym, Banku Światowym czy UNESCO. Zdaniem neorealistów instytucje wymuszają między państwami współpracę, pełniąc tym samym funkcję stabilizatora ładu międzynarodowego. W przypadku Chin i Tajwanu lepiej sprawdzi się sceptyczne stanowisko zaprezentowane przez Kennetha Waltza, który stwierdził, że organizacje nie posiadając władzy zwierzchniej nad państwami, nie są w stanie zapanować nad anarchicznym systemem międzynarodowym ${ }^{35}$.

Istotną rolę w konflikcie chińsko-tajwańskim odgrywają również wspomniane działania Stanów Zjednoczonych. Wraz z końcem zimnej wojny wyłonił się nowy porządek międzynarodowy. Upadek systemu bipolarnego nie zagroził USA - jednemu z największych rywali Chin. Nastał swoisty Pax Americana - bezsporna przewaga USA, uznawanych za światowego lidera, które niejednokrotnie aktywizowały swoje działania w regionie Azji i Pacyfiku. Od początku Tajwan warunkował pozycję strategiczną

33 Z perspektywy prawa międzynarodowego było niedopuszczalne, żeby jedno państwo (jeśli uznajemy jedność Chin) reprezentowały dwa rządy. L. Antonowicz, op.cit., s. 33-37; K.Y. Koopman, Taiwan's path to independence: resolving the „one China” dispute, http://cardozojcr.com/wp-content/uploads/2016/11/CAC107_crop.pdf [dostęp: 21.08.2017].

34 J. Czaputowicz, Bezpieczeństwo międzynarodowe. Wspótczesne koncepcje, Warszawa 2012, s. 104; K.A. Lieber, War, peace, and international political realism: perspectives from the review of politics, Notre Dame 2009, s. 8.

35 K. Gruszko, Rola organizacji międzynarodowych w kreowaniu globalnego tadu międzynarodowego, [w:] Poziomy analizy..., op.cit., s. 278-280. 
USA na Dalekim Wschodzie. Oficjalnie przyznano, że w przypadku konfliktu zbrojnego USA będą mogły wykorzystać położenie wysp do operacji lotnictwa, jak również kontroli ruchu żeglugowego. Ponadto Tajwan jako główny eksporter dostarczał do Japonii żywność oraz surowce, dlatego strategicznym celem USA stało się odizolowanie wyspy od Chin. Przyczyną pierwszego kryzysu 2 grudnia 1954 r. w Cieśninie Tajwańskiej było podpisanie w Waszyngtonie Traktatu o wzajemnej obronie między USA a Republiką Chińską, co stanowiło widoczny sygnał do wykorzystania amerykańskich sił w obronie Tajwanu przed agresją ze strony Chin. Miało to ograniczyć potencjał wojenny Państwa Środka, jak również wzmocnić siłę ekonomiczną i militarną sojuszników USA w regionie. Z drugiej strony przeciwwagą dla USA w regionie mógł być w tym czasie Związek Radziecki. Nikita Chruszczow oficjalnie przyznał, że „atak na Chińską Republikę Ludową to atak na Związek Radziecki”36. Zatem opisaną sytuację można określić dylematem bezpieczeństwa - zarówno Związek Radziecki, jak i Chiny miały ograniczone zaufanie do USA, których rozwój wojskowy $\mathrm{w}$ regionie przez umieszczanie na wyspie rakiet do przenoszenia głowic atomowych mógł posłużyć do ataku. Dopiero w 1979 r. USA uznały rząd w Pekinie za jedyny legalny rząd $\mathrm{Chin}^{37}$.

Zgodnie z podejściem realistycznym na zachowanie państwa oddziałuje struktura systemu międzynarodowego. To ona właśnie skłania je ku konkurencji i rywalizacji. Państwa pragną kontrolować wszystkich uczestników systemu przez maksymalizację siły i nie dopuszczać tym samym do uzyskania przewagi przez innych aktorów ${ }^{38}$. Niewątpliwie wszystkie działania podejmowane przez USA czy Chiny mają im zapewnić przywódczą pozycję na arenie międzynarodowej, a wszelkie posunięcia jednego z nich, traktuje się jako zagrożenie dla drugiego. Najnowsze doniesienia o nałożeniu amerykańskich sankcji na osoby oraz przedsiębiorstwa, które wspierały koreański program nuklearny, mogą doprowadzić do znacznego kryzysu w relacjach USA-Chiny. Na pozór wydaje się, że działania te nie dotyczą bezpośrednio Tajwanu, jednak sytuacja w regionie może mieć

36 A. Halimarski, Spór o Tajwan, Warszawa 1986, s. 50-84.

37 P.C.Y. Chow, The "one China" dilemma, New York 2008, s. 3-4.

38 J.J. Mearsheimer, Structural realism, [w:] International relations theories: discipline and diversity, eds. T. Dunne, M. Kurki, S. Smith, Oxford 2006, s. 73-75. 
na wyspie dalekosiężne skutki. Pogłębiająca się niestabilność na obszarze Indo-Azji-Pacyfiku wymaga od USA wykorzystania istotnego sojusznika, jakim pozostaje do dnia dzisiejszego Tajwan. 27 maja 2017 r. przedstawiono projekt doprowadzający do zwiększenia militarnego potencjału wyspy dzięki wymianie handlowej z USA. Wielki sprzymierzeniec decyduje się wesprzeć Tajwan z jednego powodu - strategiczne położenie Tajwanu wzmocnione o odpowiednie zdolności obronne pomaga uruchomić pewnego rodzaju element odstraszający dla programów Korei Północnej czy działań na Morzu Południowym ${ }^{39}$. Wobec tego Tajwan po raz kolejny staje się przedmiotem w sprawie o wielkie wpływy na obszarze Azji i Pacyfiku, gdzie polityka i przemoc przenikają się wzajemnie.

\section{Uwagi końcowe}

Analizując konflikt chińsko-tajwański, warto zwrócić uwagę na trudności powstające $w$ wyniku próby właściwego wyjaśnienia poziomów analizy Kennetha Waltza. Główną troską autorki pozostała odpowiedź na pytanie, czy któryś z opisanych szczebli można określić jako pierwszoplanowy i determinujący pozostałe. Kiedy klasyczni realiści zaniedbują inne poziomy niż państwo, neorealiści koncentrują się na "systemowej determinacji”, a realiści neoklasyczni twierdzą, że zmienne na poziomie państwowym łączą się w naturalny sposób z determinantami systemowymi. Należy mieć zatem na uwadze, że zastosowana metoda uproszczenia analizy konfliktu chińsko-tajwańskiego nie pozostaje jedyną właściwą i doskonałą. W kwestii określenia wagi jednostki, państwa czy systemu międzynarodowego autorka odeszłaby od założeń realizmu strukturalnego, zwracając się bardziej ku realistom neoklasycznym z uwagi na wzajemne oddziaływanie wpływów wewnętrznych i zewnętrznych w danym państwie. Nie można zatem zgodzić się z Kennethem Waltzem, że „wyjaśnienia na poziomie systemowym uwzględniają podstawowe zmiany w polityce światowej" ${ }^{* 0}$.

39 http://www.chinapost.com.tw/taiwan/foreign-affairs/2017/05/27/498007/us-lawmaker.htm. https://www.money.pl/gospodarka/wiadomosci/artykul/korea-rosja-usa-chiny-sankcje-atom,219,0,2357211.html. http://focustaiwan.tw/news/aipl/201705270009.aspx [dostęp: 22.08.2017].

40 A.A. Omar, op.cit. 
Takie podejście nie wykorzystałoby wielu zmiennych, więc pozostałoby w dużym stopniu ograniczone.

Przypadek Tajwanu pokazuje, że brak możliwości wypracowania jednoznacznego porozumienia można przypisać zarówno ambicjom jednostek, jak i warunkom systemowym. Między innymi dlatego do dnia dzisiejszego nie wypracowano jednoznacznego porozumienia w kwestii Tajwanu, prowadząc szczególnie po stronie Republiki Chińskiej politykę tzw. trzech nie - niekontaktowania się, nienegocjowania, nieszukania kompromisu ${ }^{41}$. W dalszym ciągu wyspa nie utrzymuje z Chinami oficjalnych kontaktów i pozostaje w stanie niekończącej się wojny domowej. Obie strony natomiast przyznają, że Tajwan należy do Chin.

Analizując słowa Johna Mearsheimera, we współczesnym świecie, jeśli Chiny chcą być potęgą, lepiej, aby były „smokiem” niż „pandą”, lecz ten silny „smok” w grze o sumie zerowej zagrozi bezpieczeństwu Tajwanu ${ }^{42}$.

mgr Natalia Sienko

Instytut Studiów Międzynarodowych

Uniwersytet Wrocławski

ul. Koszarowa 3, budynek 21, 51-149 Wrocław

natalia.s1993@wp.pl

\section{Bibliografia}

Albert E., China-Taiwan Relations, 7.12.2016, https://www.cfr.org/backgrounder/china-taiwan-relations.

Antonowicz L., Status prawnomiędzynarodowy Republiki Chińskiej na Tajwanie, [w:] Tajwan w stosunkach międzynarodowych, red. E. Haliżak, Warszawa 1997.

Bógdał-Brzezińska A., Mocarstwowość w teorii stosunków międzynarodowych, [w:] Państwo w teorii i praktyce stosunków międzynarodowych, red. M. Sułek, J. Simonides, Warszawa 2009.

41 J. Men, Globalization and cross - strait relations, [w:] Greater China in an era of globalization, eds. S. Guo, B. Guo, Lanham 2010, s. 83.

42 R. Kwieciński, op.cit., s. 382. 
Bush R.C., A One-China policy primer, „East Asia Policy Paper” 2017, No. 10. Cheng P.C., Taiwan under Chiang Kai-shek's era: 1945-1976, „Asian Profile" 1988, Vol. 16, No. 4.

Chow P.C.Y., The "one China" dilemma, New York 2008.

Czaputowicz J., Bezpieczeństwo międzynarodowe. Wspótczesne koncepcje, Warszawa 2012.

Dillon M., Chiny. Historia wspótczesna, Warszawa 2012.

Donnelly J., Realism and international relations, Cambridge 2000.

Dumbaugh K., Taiwan's political status: historical background and its implications for U.S. policy, 3.11.2009, https://fas.org/sgp/crs/row/ RS22388.pdf.

Eastman L.E., Who lost China? Chiang Kai-shek testifies, „The China Quarterly"1981, No.88.

Elleman B.A., High seas buffer. The Taiwan patrol force, 1950-1979, Newport 2012.

Fenby J., Czang Kaj-Shek i jego Chiny. Jeden z najbardziej kontrowersyjnych przywódców XX wieku, Wrocław 2003.

Gruszko K., Rola organizacji międzynarodowych w kreowaniu globalnego tadu międzynarodowego, [w:] Poziomy analizy stosunków międzynarodowych, red. E. Haliżak, M. Pietraś, t. 1, Warszawa 2013.

Halimarski A., Spór o Tajwan, Warszawa 1986.

Hobson J.A., Imperialism: a Study, London 1988.

Karnia K., China's capitalism, „Warsaw Forum of Economic Sociology” 2012, Vol. 3, No. 1 (5).

Koopman K.Y., Taiwan's path to independence: resolving the „one China" dispute, http://cardozojcr.com/wp-content/uploads/2016/11/ CAC107_crop.pdf.

Kwieciński R., Między „republika" a „imperium”? Chiny w stosunkach międzynarodowych $w$ ujęciu paradygmatu realistycznego, [w:] Teoria realizmu w nauce o stosunkach międzynarodowych: założenia i zastosowania badawcze, red. E. Haliżak, J. Czaputowicz, Warszawa 2014.

Lenin W.I., Imperializm jako najwyższe stadium kapitalizmu: szkic popularny, Warszawa 1949.

Lieber K.A., War, peace, and international political realism: perspectives from the review of politics, Notre Dame 2009. 
Łoś-Nowak T., Państwowy poziom analizy $w$ stosunkach międzynarodowych, [w:] Poziomy analizy stosunków międzynarodowych, red. E. Haliżak, M. Pietraś, t. 1, Warszawa 2013.

Matsumoto H., The First Taiwan Strait Crisis and China's 'Border' Dispute around Taiwan, „Eurasia Border Review 3” 2012.

Mearsheimer J.J., Structural realism, [w:] International relations theories: discipline and diversity, eds. T. Dunne, M. Kurki, S. Smith, Oxford 2006. Men J., Globalization and cross - strait relations, [w:] Greater China in an era of globalization, eds. S. Guo, B. Guo, Lanham 2010.

Morgenthau H., Polityka między narodami. Walka o potęgę i pokój, red. K.W. Thompson, tłum. R. Włoch, wydanie skrócone, Warszawa 2010.

Omar A.A., Is there anything 'new' in neoclassical realism?, 13.02.2013, http://www.e-ir.info/2013/02/13/is-there-anything-new-in-neoclassical-realism/.

Polit J., Chiny, Warszawa 2004.

Singer D., The level-of-analysis problem in international relations, „World Politics" 1961, Vol. 14, No. 1.

Tamaki T., Levels of analysis of the international system, [w:] Encounters with World Affairs: An Introduction to International Relations, ed. E. Kavalski, Farnham 2015.

Tanner H.M., Where Chiang Kai-shek lost China: The Liao-Shen campaign, 1948, Bloomington 2015.

Tse-Kang Leng, Dynamics of Taiwan-mainland China economic relations: the role of private firm, „Issues and Studies”, 1998, https://www.forbes. com/sites/jnylander/2015/02/14/strong-support-for-independence-in-taiwan/\#79b46457281d.

Valentini G., China and Japan's Responses to the West in the 19th Century, 4.11.2013, http://www.e-ir.info/2013/11/04/chinese-and-japanese-responses-to-the-west-during-the-19th-century/.

Vradiy S., Russia's unofficial relations with Taiwan, [w:] Eager Eyes Fixed on Eurasia, Vol. 2: Russia and Its Eastern Edge, ed. I. Akiriho, Hokkaido 2007. Waltz K.N., Man, the State, and War: A Theoretical Analysis, New York 2001.

Waltz K.N., Struktura teorii stosunków międzynarodowych, Warszawa 2010. 
William K.C., The Nationalist Regime and the Chinese Party-State, 1928-1958, [w:] Historical Perspectives on Contemporary East Asia, eds. M. Goldman, A. Gordon, Cambridge 2000.

Xing L., Shaw T.M., The political economy of Chinese state capitalism, "The Journal of China and International Relations", Vol. 1, No. 1.

Ya-Chen S., Ideological Representations of Taiwan's History: An Analysis of Elementary Social Studies Textbooks, 1978-1995, „Curriculum Inquiry" 2007, Vol. 37, No. 3.

Ya-Chen S., Political Ideology and Taiwanese School Curricula , Asia Pacific Education Review" 2006, Vol. 7, No. 1.

Zemanek B.S., Tajwańska tożsamość narodowa w publicystyce politycznej, Kraków 2008.

Zieliński P., Kryzys tajwański 1958 roku, http://www.konflikty.pl/historia/ czasy-najnowsze/kryzys-tajwanski-1958-roku/.

Ziętek A., Aktualne problemy polityki zagranicznej Republiki Chińskiej na Tajwanie, [w:] Tajwan w stosunkach międzynarodowych, red. E. Haliżak, Warszawa 1997.

\section{Wykaz stron internetowych}

http://www.chinapost.com.tw/taiwan/foreign-affairs/2017/05/27/498007/ us-lawmaker.htm.

http://focustaiwan.tw/news/aipl/201705270009.aspx.

http://www.latimes.com/world/asia/la-fg-taiwan-tsai-approval-2017-story.html.

https://www.money.pl/gospodarka/wiadomosci/artykul/korea-rosja-usa-chiny-sankcje-atom,219,0,2357211.html.

http://www.straitstimes.com/asia/east-asia/taiwan-president-vows-thorough-probe-into-1947-massacre.

\section{The Chinese-Taiwanese conflict in realist paradigm - three levels of Kenneth Waltz's analysis}

\section{Abstract}

This article attempts to systematize the possible sources and causes of the Chinese-Taiwanese conflict based on the three levels of analysis presented by Ken- 
neth Waltz. The author discusses the assumptions of realism theory (structural realism) on the basis of the modes of functioning of the individual, state, and international system. Through this analysis, it will be possible to assess the location of the various elements (forces) driving the war in the international system.

Keywords: levels of analysis, individual, state, international system, actors, political realism

\section{Сино-тайваньский конфмикт в реалистической парадигме - три уровня анахиза Кеннета Уолтца}

\section{Абстракт}

В этой статье Аелается попытка систематизировать возможные источники и причины конфликта межАу Китаем и Тайванем на основе трех уровней анализа, представленных через Кеннета Уолтца. Автор обсудит преАположения теории структурного реализма на основе способов функционирования уровня индивиАа, государства и межАународной системы. БАагодаря этому анализу можно будет оценить местоположение разАичных элементов (сик), ускорящих войну в межАународной системе.

КАючевые слова: уровни анализа, индивиА, государство, межАународная система, актёры, политический реализм 